\title{
Gneiss and steatite vermicomposted with organic residues: release of nutrients and heavy metals
}

\author{
Maria Eunice Paula de Souza ${ }^{1}$. Irene Maria Cardoso ${ }^{1} \cdot$ André Mundstock Xavier de Carvalho $^{2}$. \\ Andreia Paiva Lopes ${ }^{1} \cdot$ Ivo Jucksch $^{1}$
}

Received: 5 January 2018 / Accepted: 28 January 2019 / Published online: 5 February 2019

(C) The Author(s) 2019

\begin{abstract}
Purpose Use of silicate rock powders as fertilizer improves nutrient cycling, thus benefitting agriculture. The availability of nutrients to plants is often low, but can be increased when rock powder is vermicomposted and added. However, these powders can be rich in heavy metals, which may impair their use. We evaluated maize growth and heavy metals in plants and soil after fertilization with vermicomposted gneiss or steatite powders.

Method Vermicompost was prepared with cattle manure, with or without gneiss or steatite powders. The experimental units were kept in the dark at room temperature for 70 days. Subsequently, a greenhouse experiment was carried out with maize grown in highly weathered oxisol soil and fertilized with vermicompost alone, or with gneiss or steatite powder.

Results A small proportion of heavy metals was immobilized in the earthworm bodies, but did not hinder their growth. Maize growth was superior in the treatment with vermicomposted gneiss powder. The gneiss-enriched treatment contributed to increased $\mathrm{Zn}$ concentration in plants and may also be an alternative to $\mathrm{Zn}$ fertilization. High $\mathrm{Ni}$ and $\mathrm{Cr}$ concentrations in steatite powder apparently induced higher levels of these elements in plants. However, metal concentrations in the soil after cultivation in all the treatments were below acceptable limits.

Conclusion Increased plant growth in gneiss-enriched vermicompost suggests the possibility of using this material to enrich vermicompost with nutrients, thus improving the chemical quality of organic fertilizer. Use of steatite powder in agriculture deserves further investigation.
\end{abstract}

Keywords Fertilization $\cdot$ Stonemeal $\cdot$ Manure $\cdot$ Plant growth $\cdot$ Vermicompost

Electronic supplementary material The online version of this article (https://doi.org/10.1007/s40093-019-0244-z) contains supplementary material, which is available to authorized users.

Maria Eunice Paula de Souza

mariaeunice13@gmail.com

Irene Maria Cardoso

irene@ufv.br

André Mundstock Xavier de Carvalho

andre.carvalho@ufv.br

Andreia Paiva Lopes

andreiaplopesufv@gmail.com

Ivo Jucksch

ivo@ufv.br

1 Soil Science Department, Federal University of Viçosa, Av. P.H. Rolfs s/n, Campus Universitário Viçosa, Viçosa, MG CEP: 36570-000, Brazil

2 Institute of Agricultural Sciences, Federal University of Viçosa, Campus de Rio Paranaíba, MG 230 - Km 7, Rio Paranaíba, MG CEP: 38810-000, Brazil

\section{Introduction}

The use of silicate rock powders derived from mining tailings as fertilizer improves nutrient cycling, potentially benefitting agriculture (Theodoro and Leonardos 2006), and increasing the resistance of plants to biotic and abiotic stresses due to improvements in their nutritional status (Melamed et al. 2008). In 2013, Brazil produced 10.5 million tons of ornamental stone, sold on domestic and foreign markets. Silicate rocks, such as granite and gneiss, were among the main rock types marketed (Chiodi Filho 2014). The material loss between removal from the quarry to the final product is estimated at approximately $70 \%$. These residues are sources of plant nutrients that can help to reduce the high dependence on imported inorganic fertilizers required for agriculture (Theodoro and Leonardos 2006; IBRAM 2012; Ramos et al. 2017). Recently, Brazil changed the law to consider rock powder as a fertilizer in agriculture (Brazil 2013). 
Although rock powders can in some cases be relatively rich in certain nutrients, these nutrients are not readily available to plants since they are trapped in the crystal structure of the minerals. The nutrients can be released from the mineral structures if rock powders are added to organic waste during the process of vermicomposting (Liu et al. 2011). Vermicomposting allows the use of organic residues that are often produced on farms, thus contributing to the nutrient cycling process. The use of organic waste enriched with rock powders is, therefore, an alternative to conventional inorganic fertilizers. Higher densities of worms and increases in maize growth and biomass after vermicomposting with gneiss and steatite powders have been observed (Souza et al. 2013). However, these rock powders can be rich in heavy metals, such as $\mathrm{Cd}, \mathrm{Cu}, \mathrm{Cr}, \mathrm{Ni}, \mathrm{Pb}$, and $\mathrm{Zn}$, which may impair their use in agriculture, as the metals could become available to plants (Souza et al. 2018).

Despite the numerous uncertainties about the specificity of the mechanisms of heavy metal absorption, especially of those not essential to plant growth, the concentration and accumulation of these elements in plant tissues generally depend on their availability in the soil solution. Root and shoot concentrations can increase with increasing metal concentrations in the soil solution. The biosorption capacity of various biological materials to remove heavy metals has been studied increasingly (Ahmaruzzaman and Gupta 2011; Gupta and Saleh 2013; Gupta et al. 2015). The few studies that evaluated vermicomposting with the addition of rock powders (Wei et al. 2012; Souza et al. 2013) did not address the effects of heavy metal contained in the rock powder on their concentrations in the soil or on plant development. The main objectives of this study were to evaluate the presence of heavy metals in plants and soil and subsequent maize growth when soil was fertilized with vermicomposted rock powders. The experiment was carried out in a greenhouse and complements a study that was performed in the field (Souza et al. 2018).

\section{Materials and methods}

\section{Source and characterization of rock powder}

Steatite (or soapstone) and gneiss powders are readily found in the Zona da Mata region of Minas Gerais (Brazil), where the study was carried out. The material was air-dried and sieved $(<0.212 \mathrm{~mm}$ and $>0.106 \mathrm{~mm})$. For the chemical analysis of the rocks, a subsample was oven-dried at $65^{\circ} \mathrm{C}$ for $72 \mathrm{~h}$, ground and sieved $(<0.053 \mathrm{~mm})$. The macro-elements were analyzed by X-ray fluorescence spectrometry and atomic absorption spectrophotometry after nitro-perchloric digestion for the analysis of the other elements, as suggested by Silva (2009; Table 1).
Table 1 Chemical properties of the rock powders

\begin{tabular}{lrrrrrr}
\hline & \multicolumn{7}{c}{ Microelements $\left(\mathrm{mg} \mathrm{kg}^{-1}\right)$} \\
\cline { 2 - 7 } & $\mathrm{Cu}$ & \multicolumn{1}{c}{$\mathrm{Zn}$} & \multicolumn{1}{c}{$\mathrm{Ni}$} & $\mathrm{Cd}$ & \multicolumn{1}{c}{$\mathrm{Cr}$} & \multicolumn{1}{c}{$\mathrm{Pb}$} \\
\hline Steatite & 39 & 84 & 1556.0 & 2.6 & 1000.2 & 15.2 \\
Gneiss & 11 & 148 & 4.4 & 2.3 & 14.3 & 9.8 \\
\hline
\end{tabular}

\section{Experimental design}

A completely randomized design with three treatments and six replicates (each consisting of one pot) was used. The treatments consisted of manure mixed with $12 \%$ gneiss powder, manure mixed with $12 \%$ steatite powder, and manure without rock powder (a control treatment), all on a dryweight basis.

\section{Sourcing and evaluation of enriched vermicomposts}

Partially decomposed cattle manure was used as a basis for the vermicompost. The manure was crumbled and mixed to homogenize moisture and particle size. Subsequently, composite samples of the manure were taken, wrapped in paper bags and dried $\left(65^{\circ} \mathrm{C}\right)$ in a forced-air circulation oven (72 h). Once dry, the samples were weighed, ground and sieved $(<2 \mathrm{~mm})$. A sample of this material was digested in a nitro-perchloric acid mixture, and the contents of $\mathrm{Cu}$ $\left(13.0 \mathrm{mg} \mathrm{kg}^{-1}\right), \mathrm{Zn}\left(63.0 \mathrm{mg} \mathrm{kg}^{-1}\right), \mathrm{Ni}\left(12.2 \mathrm{mg} \mathrm{kg}^{-1}\right), \mathrm{Cd}$ (1.0 $\left.\mathrm{mg} \mathrm{kg}^{-1}\right), \mathrm{Cr}\left(28.7 \mathrm{mg} \mathrm{kg}^{-1}\right)$, and $\mathrm{Pb}\left(13.6 \mathrm{mg} \mathrm{kg}^{-1}\right)$ were quantified with a Perkin-Elmer atomic absorption spectrophotometer model 730 (Silva 2009).

Eisenia andrei worms, with an average weight of $0.560 \mathrm{~g}$ per adult, were used to vermicompost the manure mixed with rock powder. To eliminate the remains of the previous food from the intestines of the animals, they were incubated in manure for 1 week before initiating the experiment. To prepare the vemicompost, 18 plastic pots (5 1 each) were filled with $3.0 \mathrm{~kg}$ cattle manure (dry weight). Six of these pots received $400 \mathrm{~g}$ gneiss powder, six others received $400 \mathrm{~g}$ of steatite powder and six did not receive any rock powder. Twenty-four adult worms were added to each pot. The experimental units were kept in the dark at room temperature for 70 days.

At the end of the vermicomposting process, the earthworms were removed by hand, transferred to containers with clean water, and left there for $24 \mathrm{~h}$ to eliminate the content of the digestive tract as much as possible. Thereafter, they were dried at $65^{\circ} \mathrm{C}$ for $72 \mathrm{~h}$, ground and digested in a nitro-perchloric acid mixture and the concentrations $\mathrm{Cu}, \mathrm{Zn}, \mathrm{Ni}, \mathrm{Cd}$, $\mathrm{Cr}$, and $\mathrm{Pb}$ (heavy metals) in the extracts were determined with a Perkin-Elmer atomic absorption spectrophotometer model 730 (Silva 2009). 
Samples of the vermicompost were taken from each plastic pot for chemical analyses. The dry material was ground, digested in nitro-perchloric acid mixture and the $\mathrm{Cu}, \mathrm{Zn}, \mathrm{Ni}$, $\mathrm{Cd}, \mathrm{Cr}$, and $\mathrm{Pb}$ concentrations were determined by atomic absorption spectrophotometry (Silva 2009). The maximum concentrations of heavy metal permitted in organic fertilizers, soil and plants, according to regulations from Brazil, the European Union (EU) and the United States of America (USA), are listed in Table 2.

\section{Evaluation of growth and availability of heavy metals in the plants}

A greenhouse experiment was carried out with the vermicompost to evaluate plant growth and the presence of heavy metals in the roots and shoots of maize (Landrace variety Asteca). The chemical properties of the highly weathered oxisol soil used in the experiment were: $\mathrm{pH}$ (5.1), $\mathrm{P}\left(1.1 \mathrm{mg} \mathrm{dm}^{-3}\right) ; \mathrm{K}\left(4.0 \mathrm{mg} \mathrm{dm}^{-3}\right), \mathrm{Ca}^{+2}\left(0.21 \mathrm{cmol}_{\mathrm{c}} \mathrm{dm}^{-3}\right)$, $\mathrm{Mg}^{+2}\left(0.02 \mathrm{cmol}_{\mathrm{c}} \mathrm{dm}^{-3}\right)$, and $\mathrm{Al}^{+3}\left(0.7 \mathrm{cmol}_{\mathrm{c}} \mathrm{dm}^{-3}\right)$. Potential cation exchange capacity at $\mathrm{pH} 7.0$ was $2.36 \mathrm{cmol}_{\mathrm{c}} \mathrm{dm}^{-3}$, organic matter was $1.2 \mathrm{dag} \mathrm{kg}^{-1}$, Cu was $0.1 \mathrm{mg} \mathrm{kg}^{-1}$, and $\mathrm{Zn}$ was $0.2 \mathrm{~m} \mathrm{~kg}^{-1}$; levels of $\mathrm{Ni}, \mathrm{Cd}, \mathrm{Cr}$ and $\mathrm{Pb}$ were not determined. The soil for the experiment was prepared 15 days prior to planting by mixing with dolomitic limestone and with the same partially decomposed cattle manure that was used to prepare the vemicompost. The limestone contained $\mathrm{Ni}\left(72.0 \mathrm{mg} \mathrm{kg}^{-1}\right), \mathrm{Cd}\left(5.7 \mathrm{mg} \mathrm{kg}^{-1}\right), \mathrm{Cr}\left(50.1 \mathrm{mg} \mathrm{kg}^{-1}\right), \mathrm{Pb}$ (66.7 $\mathrm{mg} \mathrm{kg}^{-1}$ ), $\mathrm{CaO}$ (38.7\%), and $\mathrm{MgO}$ (10.7\%). Eighteen plastic pots were each filled with $3.0 \mathrm{~kg}$ of the soil, $7.5 \mathrm{~g}$ of cattle manure and $3 \mathrm{~g}$ of limestone. Prior to planting, a dose corresponding to $50 \mathrm{tha}^{-1}$ of either of the vermicomposts enriched with steatite powder $(77 \mathrm{~g})$ or gneiss powder $(79 \mathrm{~g})$ was added to each pot.

Three seeds of maize were sown in each pot and seedlings were thinned to two after germinating. Soil humidity was monitored and maintained at approximately $70 \%$ field capacity. The three treatments were arranged in a completely randomized design with six replicates.

The plants were cut at soil level at the onset of flowering (45 days) to determine the shoot dry mass. All plant material was washed in a sequence of dilute hydrochloric acid (10\%), tap water and distilled water. Subsequently, the material was packed in paper bags and dried at $65^{\circ} \mathrm{C}$ in a forced-air circulation oven for $72 \mathrm{~h}$. Once dry, all material was weighed, ground, sieved $(<2 \mathrm{~mm})$, and stored for later analysis. The samples were digested in a nitro-perchloric acid mixture, and $\mathrm{Cu}, \mathrm{Zn}, \mathrm{Ni}, \mathrm{Cd}, \mathrm{Cr}$, and $\mathrm{Pb}$ concentrations were assessed as above. The heavy metals found in the maize shoots and roots and in the soil after cultivation were regarded as having been made available in the vermicomposting process.

\section{Evaluation of heavy metals in soil post-cultivation}

After harvesting the plants, soil samples were collected from each pot for chemical analysis. The samples were air-dried and sieved $(<2 \mathrm{~mm})$. The $\mathrm{pH}$ was determined in a soil:water suspension (1:2.5). The available $\mathrm{Cu}, \mathrm{Zn}, \mathrm{Ni}, \mathrm{Cd}, \mathrm{Cr}$, and $\mathrm{Pb}$ were extracted by Mehlich- 1 and determination of levels and metal concentrations was performed as above.

\section{Statistical analysis}

Since we measured several response variables from the same replicates, we first performed MANOVAs for the heavy metals found in the earthworms, in the composts, in the plant shoots and roots and in the soil at the end of the experiment. Since we found no detectable quantities of $\mathrm{Cd}$ in the vermicompost and the shoots and roots, and of $\mathrm{Pb}, \mathrm{Cr}, \mathrm{Ni}$ and $\mathrm{Cd}$ in the soil, these metals were excluded from the MANOVA analysis. Subsequently, individual heavy metals were compared among treatments with means tests. Weight of shoots and roots was also analyzed combined with a MANOVA, followed by a means test procedure for
Table 2 Maximum concentrations $\left(\mathrm{mg} \mathrm{kg}^{-1}\right)$ of heavy metals allowed in organic fertilizers, soil and plants in Brazil, the EU and the USA

\begin{tabular}{|c|c|c|c|c|c|c|c|}
\hline & & $\mathrm{Cu}$ & $\mathrm{Zn}$ & $\mathrm{Ni}$ & $\mathrm{Cd}$ & $\mathrm{Cr}$ & $\mathrm{Pb}$ \\
\hline Organic & Brazil $^{(1)}$ & No limit ${ }^{(5)}$ & No limit & 70 & 3 & 200 & 150 \\
\hline \multirow[t]{2}{*}{ Fertilizer } & $\mathrm{EU}^{(2)}$ & $33-60$ & $109-347$ & $4-44$ & $0.2-0.7$ & $5-56$ & $5-18$ \\
\hline & $\mathrm{USA}^{(3)}$ & $2-172$ & $15-556$ & SL & $0.1-0.8$ & $1.1-55$ & $1.1-27$ \\
\hline \multirow[t]{3}{*}{ Soil } & Brazil $^{(1)}$ & 49 & 46.5 & 21.5 & $<0.4$ & 75 & 19.5 \\
\hline & $E U^{(3)}$ & $50-140$ & $150-300$ & $20-75$ & $1-3$ & $100-150$ & $50-300$ \\
\hline & $\mathrm{USA}^{(3)}$ & $60-125$ & $400-700$ & 100 & $3-8$ & $75-400$ & $100-400$ \\
\hline \multirow[t]{3}{*}{ Plant } & Brazil $^{(1)}$ & 30 & 50 & 5 & 0.5 & 0.1 & 0.5 \\
\hline & $\mathrm{EU}^{(2)}$ & No limit & No limit & No limit & 0.2 & No limit & 0.3 \\
\hline & $\mathrm{USA}^{(4)}$ & $5-20$ & $10-50$ & $1-10$ & $0.05-0.5$ & 2 & $0.5-10$ \\
\hline
\end{tabular}

(1) MAPA (2006), COPAM (2011), ANVISA (1965, 1998); ${ }^{(2)}$ European Commission (2006); ${ }^{(3)}$ Alloway (2013); ${ }^{(4)}$ Kabata-Pendias (2010); ${ }^{(5)}$ No threshold established by the normative regulation 
shoots and roots separately. We evaluated the homogeneity of variances and normality of residuals using Bartlett and Jarque-Bera tests. Analysis of variance was performed and the means tested by Student-Newman-Keuls (SNK) at 5\% probability.

\section{Results and discussion}

The dry weight of earthworms differed significantly among treatments $\left(\mathrm{F}_{2,15}=36.5 ; p<0.001\right)$, and was highest with the gneiss vermicompost $(4.25 \mathrm{~g}$; $\mathrm{se}=0.21)$, lower with the steatite-enriched compost $(2.78 \mathrm{~g}$; se $=0.16)$ and still lower with the non-enriched compost $(2.11 \mathrm{~g}$; se $=0.16)$. The differences among all composts were significant (contrasts with SNK test, $p<0.05$ ). Despite the presence of heavy metals in the silicate rocks (Table 1), the earthworm weights indicate that the inclusion of rock powders in vermicomposting was not harmful, but rather favorable for the growth and reproduction of these animals, which confirms earlier findings (Souza et al. 2013).

Overall, there was a significant effect of vermicompost type on the concentrations of heavy metals in the body of the earthworms (MANOVA, Pillai-Bartlett statistic $=1.99$, $p<0.0001)$. The concentrations of $\mathrm{Cu}\left(\mathrm{F}_{2,15}=49.2\right.$; $p<0.001)$, Ni $\left(\mathrm{F}_{2,15}=21.3 ; p<0.001\right), \mathrm{Cr}\left(\mathrm{F}_{2,15}=820.7\right.$, $p<0.001)$ and $\mathrm{Cd}\left(\mathrm{F}_{2,15}=30.2 ; p<0.001\right)$ differed significantly among treatments (Table 3 ). They were higher with steatite and did not differ between gneiss and unenriched vermicompost. The concentrations of $\mathrm{Zn}\left(\mathrm{F}_{2,15}=6807.5\right.$; $p<0.001)$ and $\mathrm{Pb}\left(\mathrm{F}_{2,15}=128.3 ; p<0.001\right)$ in earthworms also differed significantly among treatments. They were higher with gneiss-enriched vermicompost (Table 3). Some of these metals, such as $\mathrm{Cu}$ and $\mathrm{Zn}$, are constituents of the animal body in minute concentrations. Associated with some proteins, these elements move within the animal body, participating in several reactions in the organism (Andriguetto et al. 1998).

Overall, there was a significant effect of compost type on the heavy metal concentrations in the vermicomposts
(MANOVA, Pillai-Bartlett statistic $=1.95, p<0.0001$ ). The concentrations of $\mathrm{Ni}\left(\mathrm{F}_{2,15}=1614.7 ; p<0.001\right)$ and Cr $\left(\mathrm{F}_{2,15}=4809 ; p<0.001\right)$ differed significantly among composts (Table 3 ). They were considerably higher in the steatite-enriched vermicompost than in the other composts. Although the concentrations of these metals were rather high, reflecting the high concentration of these elements present in the steatite (Table 1), only the Ni concentration $\left(182.8 \mathrm{mg} \mathrm{kg}^{-1}\right)$ was higher than allowed under Brazilian legislation (Table 2). The $\mathrm{Zn}$ concentrations differed significantly among treatments $\left(\mathrm{F}_{2,15}=2455.4 ; p<0.001\right)$ and was higher in gneiss-enriched vermicompost. The $\mathrm{Cu}$ concentrations varied significantly with treatments $\left(\mathrm{F}_{2,15}=9.5\right.$; $p=0.002)$; it did not differ between the steatite-enriched vermicompost and the unenriched vermicompost, but was lower in the vermicompost with gneiss (Table 3). $\mathrm{Pb}$ concentrations also differed significantly among treatments $\left(\mathrm{F}_{2,15}=15.8 ; p<0.001\right)$. It did not differ between the gneiss and steatite-enriched vermicompost, but was lower in the unenriched vermicompost (Table 3). No Cd was detected in any of the vermicompost treatments.

High heavy metal concentrations of $\mathrm{Ni}$ and $\mathrm{Cr}$ in the vermicomposts should not be ascribed to the rock powders only, as these elements were also present in manure. For instance, the concentrations of $\mathrm{Ni}, \mathrm{Cr}$ and $\mathrm{Pb}$ in the manure were higher than in gneiss powder (as shown above). The presence of heavy metals in the manure can be attributed to feed supplements for cattle (Marçal et al. 2005), chemical fertilizers and pesticides applied to the cattle's pasture. Although the heavy metal concentrations in the manure were higher than in gneiss powder, the concentrations are below the limit allowed under Brazilian regulation for organic and inorganic fertilizers in both materials (MAPA 2006, Table 2).

Overall, there was a significant effect (MANOVA, Pillai-Bartlett statistic $=1.99, p<0.0001)$ of vermicompost type on the concentrations of heavy metals in the roots (Table 4). The $\mathrm{Cu}$ concentration $\left(\mathrm{F}_{2,15}=50.6 ; p<0.001\right)$ did not differ between the steatite-enriched compost and the unenriched compost, but was lower in the compost with gneiss. Zinc concentration was higher in gneiss

Table 3 Mean metal concentrations $(n=6$; standard error) in the vermicomposts at the end of vermicomposting with cattle manure with steatite powder $(\mathrm{VcS})$, or gneiss powder $(\mathrm{VcG})$, or without rock powder $(\mathrm{Vc})$

\begin{tabular}{|c|c|c|c|c|c|c|}
\hline & $\mathrm{Cu}$ & $\mathrm{Zn}$ & $\mathrm{Ni}$ & $\mathrm{Cd}$ & $\mathrm{Cr}$ & $\mathrm{Pb}$ \\
\hline \multicolumn{7}{|c|}{ Vermicomposts } \\
\hline $\mathrm{VcS}$ & $25.7(1.42)^{\mathrm{a}}$ & $35.9(0.09)^{\mathrm{b}}$ & $281.7(3.43)^{\mathrm{a}}$ & ud & $119.6(7.64)^{\mathrm{a}}$ & $7.0(0.42)^{\mathrm{a}}$ \\
\hline $\mathrm{VcG}$ & $19.4(1.02)^{\mathrm{b}}$ & $42.8(0.25)^{\mathrm{a}}$ & $10.5(0.03)^{\mathrm{b}}$ & ud & $17.4(0.52)^{\mathrm{b}}$ & $6.7(0.23)^{\mathrm{a}}$ \\
\hline $\mathrm{Vc}$ & $24.8(0.76)^{\mathrm{a}}$ & $21.4(0.26)^{\mathrm{c}}$ & $4.9(0.12)^{\mathrm{c}}$ & ud & $15.8(0,05)^{\mathrm{c}}$ & $4.0(0.19)^{\mathrm{b}}$ \\
\hline
\end{tabular}

For each metal, means followed by different letters differ significantly (SNK test, $p<0.05$ )

All values are in $\mathrm{mg} \mathrm{kg}^{-1}$

$u d$ undetected 
vermicompost than in the steatite-enriched compost and both of these treatments were higher than in the control $\left(\mathrm{F}_{2,15}=335.6, p<0.001\right)$, being slightly above the reported range (18.2-21.5 mg kg-1) for maize 45 days after germination (Ferreira et al., 2001). The Ni concentrations differed among all treatments $\left(\mathrm{F}_{2,15}=304.0 ; p<0.001\right)$, being higher in the steatite-enriched compost than in the other treatments. Chromium concentrations differed significantly among treatments $\left(\mathrm{F}_{2,15}=105.3 ; p<0.001\right)$, was highest with the steatite-enriched vermicompost, and was lowest in the vermicompost without rock powder (Table 4). Lead concentrations varied significantly with treatment $\left(\mathrm{F}_{2,15}=63.3\right.$; $p<0.001$ ), did not differ significantly between gneissenriched vermicompost and unenriched compost, and were higher in the vermicompost with steatite (Table 4).

Overall, there was a significant effect (MANOVA, Pillai-Bartlett statistic $=1.98, p<0.0001)$ of vermicompost type on the concentrations of heavy metals in shoots (Table 4). $\mathrm{Cu}$ concentrations did not differ significantly with treatments $\left(\mathrm{F}_{2,15}=1.1 ; p=0.324\right)$. Zinc concentrations differed significantly among treatments $\left(\mathrm{F}_{2,15}=335.6\right.$, $p<0.001$ ), was higher in compost with gneiss than in the other treatments and was lowest in the vermicompost without rock powder. Nickel concentrations differed among treatments $\left(\mathrm{F}_{2,15}=304.0 ; p<0.001\right)$, was higher in the treatment with steatite than in the other treatments and was lowest in the vermicompost without rock powder. Cadmium was not detected in any of the treatments. Chromium concentrations differed among treatments $\left(\mathrm{F}_{2,15}=7070.3 ; p<0.001\right)$, and were higher in plant shoots in the steatite treatment than in the other treatments. Lead concentrations differed among treatments $\left(\mathrm{F}_{2,15}=8.73 ; p=0.003\right)$, and were lower in the treatments enriched with gneiss powder than in the other treatments.
The concentrations of $\mathrm{Cu}, \mathrm{Zn}$ and $\mathrm{Cd}$ in the roots (Table 4) were below the maximum tolerance limits for plants. Copper concentrations in roots were close to the range reported suitable for maize plants (6-20 mg kg${ }^{-1}$, Malavolta 2006). The optimal $\mathrm{Zn}$ levels in the leaves of maize plants are between 15 and $50 \mathrm{mg} \mathrm{kg}^{-1}$ (Malavolta 2006). The addition of rock powders, mainly of gneiss powder, contributed to increases of $\mathrm{Zn}$ levels in the plants.

Overall, there was a significant effect of vermicompost type on the concentrations of heavy metals in the dry weight of plants (shoots plus roots) (MANOVA, Pillai-Bartlett statistic $=1.01, p<0.0001)$. The dry weight of plants differed among treatments $\left(\mathrm{F}_{2.15}=75.6 ; p<0.001\right)$ and was higher with steatite $(7.99 \mathrm{~g}$; $\mathrm{se}=0.12)$ than with gneiss $(6.90 \mathrm{~g}$; $\mathrm{se}=0.15)$ and, in turn, higher than in the control $(5.92 \mathrm{~g}$; $\mathrm{se}=0.11$, SNK test, $p<0.05$ ). The higher gain in dry matter of plants grown with vermicompost enriched with rock powders shows the potential for the enrichment of manure with these powders for soil fertilization. The increased dry matter was probably due to an increase of the availability of nutrients and an increase of the soil nutrient pools when adding rock powders to vermicomposting (Souza et al. 2013).

The use of gneiss powder can be an alternative for $\mathrm{Zn}$ fertilization, one of the most limiting micronutrients for the productivity of many crops in Brazil, including coffee, in which $\mathrm{Zn}$ deficiency is common. The region of Zona da Mata in Minas Gerais, where gneiss is the predominant rock, is considered one of the major coffee growing regions in Brazil and farmers successfully use rock powders (particularly granite and gneiss) to improve coffee yield and quality (Cupertino et al. 2015).

The concentrations in the roots and shoots (Table 4) of Ni in the compost with steatite in all treatments exceeded the upper limits for plants defined by the Brazilian regulation
Table 4 Mean heavy metal concentrations $(n=6$; standard error) in the roots and shoots of maize in soils fertilized with vermicompost enriched with steatite $(\mathrm{VcS})$, gneiss $(\mathrm{VcG})$ or with no rock powder $(\mathrm{Vc})$

\begin{tabular}{|c|c|c|c|c|c|c|}
\hline & $\mathrm{Cu}$ & $\mathrm{Zn}$ & $\mathrm{Ni}$ & $\mathrm{Cd}$ & $\mathrm{Cr}$ & $\mathrm{Pb}$ \\
\hline \multicolumn{7}{|l|}{ Roots } \\
\hline $\mathrm{VcS}$ & $13.9(0.54)^{\mathrm{a}}$ & $23.4(0.11)^{\mathrm{b}}$ & $5.1(0.56)^{\mathrm{a}}$ & ud & $41.7(0.38)^{\mathrm{a}}$ & $4.2(0.36)^{\mathrm{a}}$ \\
\hline $\mathrm{VcG}$ & $7.5(0.35)^{\mathrm{c}}$ & $30.8(0.15)^{\mathrm{a}}$ & $1.4(0.14)^{\mathrm{b}}$ & ud & $4.2(0.15)^{\mathrm{b}}$ & $1.4(0.06)^{b}$ \\
\hline $\mathrm{Vc}$ & $11.4(0.46)^{\mathrm{a}}$ & $12.9(1.79)^{\mathrm{c}}$ & $0.5(0.02)^{\mathrm{c}}$ & ud & $0.7(0.12)^{\mathrm{c}}$ & $1.7(0.12)^{b}$ \\
\hline \multicolumn{7}{|l|}{ Shoots } \\
\hline $\mathrm{VcS}$ & $5.7(0.25)^{\mathrm{a}}$ & $4.4(0.13)^{\mathrm{b}}$ & $12.8(0.75)^{\mathrm{a}}$ & ud & $21.1(0.12)^{\mathrm{a}}$ & $2.8(0.16)^{\mathrm{a}}$ \\
\hline $\mathrm{VcG}$ & $5.3(0.30)^{\mathrm{a}}$ & $7.2(0.08)^{\mathrm{a}}$ & $6.6(1.32)^{\mathrm{b}}$ & ud & $4.7(0.19)^{\mathrm{b}}$ & $1.5(0.18)^{b}$ \\
\hline $\mathrm{Vc}$ & $5.6(0.65)^{\mathrm{a}}$ & $3.5(0.08)^{\mathrm{c}}$ & $4.4(0.12)^{\mathrm{c}}$ & ud & ud & $2.1(0.31)^{\mathrm{a}}$ \\
\hline \multicolumn{7}{|c|}{ Post-cultivated soil } \\
\hline $\mathrm{VcS}$ & $0.4(0.04)^{\mathrm{a}}$ & $0.5(0.03)^{\mathrm{a}}$ & $0.1(0.75)^{\mathrm{a}}$ & ud & ud & $0.2(0.08)^{\mathrm{a}}$ \\
\hline $\mathrm{VcG}$ & $0.4(0.04)^{\mathrm{a}}$ & $0.4(0.03)^{\mathrm{a}}$ & $0.2(0.15)^{\mathrm{a}}$ & ud & ud & ud \\
\hline $\mathrm{Vc}$ & $0.4(0.05)^{\mathrm{a}}$ & $0.5(0.06)^{\mathrm{a}}$ & $0.1(0.12)^{\mathrm{a}}$ & ud & ud & $0.1(0.08)^{\mathrm{a}}$ \\
\hline
\end{tabular}

For each metal, means followed by different letters differ significantly (SNK test, $p<0.05$ )

All values are in $\mathrm{mg} / \mathrm{kg}^{-1}$

ud undetected 
(ANVISA 1965, 1998), and the maximum suggested by Kabata-Pendias (2010) and for the United States of America (Table 2). Ni, present in high concentrations in the steatite powder (Table 1), was recently acknowledged as an essential element for plants, and its toxicity to plants was also recently studied. Nickel tends to accumulate in maize leaves and grains. However, the Ni levels expected in plants vary largely. According to Mengel and Kirkby (2001), Ni contents in plant dry matter ranged from 0.1 to $5 \mathrm{mg} \mathrm{kg}^{-1}$, whereas the Ni levels in food plants grown in United States of America ranged from 1 to $10 \mathrm{mg} \mathrm{kg}^{-1}$ (Kabata-Pendias 2010). The values reported in our experiment exceeded the maximum threshold defined by Brazilian regulation for maize grains (Table 2), but no limit was defined for the shoots, as analyzed here. However, our data are within the acceptance range defined for the United States of America (Table 4, Kabata-Pendias 2010).

The results show that adding rock powder, especially steatite, resulted in increased availability of chromium to the plants. There is no evidence that $\mathrm{Cr}$ is essential for the metabolism of plants (Kabata-Pendias and Mukherjee 2007). In general, available $\mathrm{Cr}$ accumulates in the roots, forming barriers that decrease its translocation to the shoots (Losi et al. 1994). The plants showed no visual symptoms of toxicity, but Cr concentrations, especially in plants grown on steatite-enriched compost, exceeded the maximum threshold for human food, according to under Brazilian regulation (ANVISA 1965, 1998), the maximum suggested by World Health Organization for the European Union and for the United States of America (Kabata-Pendias 2010) (Table 2). Therefore, $\mathrm{Cr}$ concentrations in the maize plants (shoot + root) are somewhat worrying. However, since the content of $\mathrm{Cr}$ in the shoots was lower than in the roots, we also expect lower content in the grain, the edible part of the plant.

The $\mathrm{Pb}$ concentrations in all the treatments exceeded the upper limits for plants defined by Brazilian regulation for maize grains (Table 2). The $\mathrm{Pb}$ found in roots and shoots is below the threshold toxicity to maize $\left(56.0 \mathrm{mg} \mathrm{kg}^{-1}\right.$, KabataPendias 2010). The roots can take up significant amounts of heavy metals such as $\mathrm{Pb}$, of which, in general, little is translocated to plant shoots (Malavolta 2006; Shtangeeva et al. 2011).

Overall, there was not a significant effect (MANOVA, Pillai-Bartlett statistic $=0.32, p=0.253$ ) of vermicompost type on the concentrations of heavy metals in the soil after cultivation (Table 4$). \mathrm{Pb}$ was not detected in the gneiss-enriched soil, and $\mathrm{Cd}$ and $\mathrm{Cr}$ were not detected in any of the treatments. In all the treatments, the metal concentrations were below the reference values for soil quality, defined by the state of Minas Gerais, Brazil, regulations (COPAM 2011), and maximum limits suggested by Alloway (2013) for the European Union and United States of America (Table 2). Probably, the soil immobilized the metals present in the vermicomposts. Soil organic matter can complex metals present in the soil solution, and thereby decrease the toxicity of pollutants (Dumat et al. 2006). Organic matter has a great affinity for heavy metals in the soil because of its adsorption properties, acting via ionic bonds and its action as a chelating agent in the soil solution (Jeong et al. 2007).

The balance of $\mathrm{Ni}, \mathrm{Cr}$ and $\mathrm{Pb}$, based on the main inputs and outputs of the metals in the treatments with rock powders, namely manure, earthworms, vermicompost, substrate (soil, cattle manure, limestone and vermicompost) and plants, is found in Table 5. The heavy metal contents found in limestone are not separately listed in the balance chart,
Table 5 Balance of $\mathrm{Ni}, \mathrm{Cr}$ and $\mathrm{Pb}$ in maize considering the main inputs and outputs of the metals in the treatments with rock powder (Steatite, $\mathrm{S}$ or Gneiss, G)

\begin{tabular}{|c|c|c|c|c|c|c|}
\hline & $\begin{array}{l}\text { Rock powder } \\
(\mathrm{S} \text { or } \mathrm{G})^{1}\end{array}$ & $\begin{array}{l}\text { Manure } \\
(\mathrm{Mc})\end{array}$ & $\begin{array}{l}\text { Earthworm } \\
(\mathrm{W})^{2}\end{array}$ & $\begin{array}{l}\text { Vermicompost } \\
(\mathrm{VcS} \text { or } \mathrm{VcG})^{3}\end{array}$ & Substrate $^{4}$ & $\begin{array}{l}\text { Maize } \\
(\mathrm{DM})^{5}\end{array}$ \\
\hline \multicolumn{7}{|c|}{$(\mathrm{S}$ or $\mathrm{G}+\mathrm{Mc}-\mathrm{W}) / \mathrm{mg} \mathrm{pot}^{-1}$} \\
\hline \multicolumn{7}{|c|}{ Steatite } \\
\hline $\mathrm{Ni}$ & 622.5 & 36.5 & 0.46 & 658.5 & 15.2 & 0.10 \\
\hline $\mathrm{Cr}$ & 400.1 & 86.0 & 0.47 & 485.6 & 11.3 & 0.19 \\
\hline $\mathrm{Pb}$ & 6.1 & 40.7 & 0.02 & 46.8 & 1.4 & 0.02 \\
\hline \multicolumn{7}{|c|}{ Gneiss } \\
\hline $\mathrm{Ni}$ & 1.8 & 36.5 & 0.29 & 38.0 & 1.2 & 0.04 \\
\hline $\mathrm{Cr}$ & 5.7 & 86.0 & 0.20 & 91.5 & 2.5 & 0.03 \\
\hline $\mathrm{Pb}$ & 3.9 & 40.7 & 0.03 & 44.6 & 1.3 & 0.01 \\
\hline
\end{tabular}

The maize was cultivated in pots, with soil fertilized with vermicompost enriched either with steatite (VcS) or gneiss $(\mathrm{VcG})$

${ }^{1}$ Metal in $400 \mathrm{~g}$ of rock powder (steatite or gneiss); ${ }^{2}$ Metal content of earthworms removed from the vermicomposts (based on Table 3); ${ }^{3}$ the vermicompost was prepared with $3000 \mathrm{~g}$ cattle manure and either $400 \mathrm{~g}$ steatite powder ( $\mathrm{VcS}$, dry weight) or with gneiss powder ( $\mathrm{VcG}$, dry weight); ${ }^{4}$ prepared with $3 \mathrm{~kg}$ of soil (no heavy metals detected), $7.5 \mathrm{~g}$ manure (Mc, dry weight), $3 \mathrm{~g}$ dolomitic lime and either $77 \mathrm{~g}$ of $\mathrm{VcS}$ or $79 \mathrm{~g}$ of $\mathrm{VcG} ;{ }^{5}$ Dry matter of the plant (root + shoot) 
since all the treatments received the same dose, i.e., $3 \mathrm{~g}$ of limestone. The contribution of the steatite powder to the substrate is 17 times more for $\mathrm{Ni}$ and 4.7 times more for $\mathrm{Cr}$ than that of manure (Table 5). In turn, the manure contributed approximately 6.7 times more $\mathrm{Pb}$ to the substrate than steatite powder. Gneiss powder contributed less $\mathrm{Ni}, \mathrm{Cr}$ and $\mathrm{Pb}$ to the substrate than did the manure $(21.5,15$, and 10.4 times less, respectively). Therefore, in the case of gneiss powder, the plant possibly extracted most of these elements from the manure, because the concentrations in gneiss powder were lower than in the manure. This suggests that greater care has to be taken when considering the quality of the supplements for animal feed (Marçal et al. 2005). Maize plants extracted low quantities of $\mathrm{Ni}, \mathrm{Cr}$ and $\mathrm{Pb}$ from the substrate (Table 5), which can be attributed to the immobilization of these metals by the soil and to the ability of selective uptake of elements by the plants (Kabata-Pendias 2010).

\section{Conclusions}

Gneiss powder improved plant growth and the chemical quality of the vermicompost, and did not induce high levels of heavy metals in the plants and soil. Therefore, there is scope for it to be added to the substrate to be vermicomposted and it should be considered a source of nutrients for agriculture and not a waste. The use of steatite powder as a fertilizer should be treated with caution and requires further study because of the high amount of $\mathrm{Ni}$ and $\mathrm{Cr}$ that is available to plants.

Acknowledgements The Brazilian Federal Agency for Support and Evaluation of Graduate Education (CAPES) and Foundations for Supporting Research in the States of Minas Gerais (FAPEMIG) are thanked for the postdoctoral grant of MEP Souza. We are also indebted to the CNPq (Edict MCTI/CT - Agribusiness/CNPq No. 38/2013), for funding the research. We are thankful to Anna-Lotta Krüger, from Wageningen University, who collaborated with the laboratory, to Arne Janssen (University of Amsterdam) and to Jonathan Majer (Curtin University) for comments on the manuscript. The comments of three anonymous referees also contributed to the production of this paper.

Open Access This article is distributed under the terms of the Creative Commons Attribution 4.0 International License (http://creativecommons.org/licenses/by/4.0/), which permits unrestricted use, distribution, and reproduction in any medium, provided you give appropriate credit to the original author(s) and the source, provide a link to the Creative Commons license, and indicate if changes were made.

\section{References}

Ahmaruzzaman M, Gupta VK (2011) Rice husk and its ash as low-cost adsorbents in water and wastewater treatment. Ind Eng Chem Res. https://doi.org/10.1021/ie201477c
Alloway BJ (2013) Heavy metals in soils: trace metals and metalloids in soils and their bioavailability. Blackie Academic \& Professional, London. https://doi.org/10.1007/978-94-007-4470-7

Andriguetto JM, Perly L, Minardi I, Gemael A, Flemming JS, Souza GA, Bona Filho A (1998) Nutrição animal: as bases e os fundamentos da nutrição animal. Nobel, São Paulo, p 183

ANVISA (Brazilian Health Regulatory Agency) (1965) Decreto ${ }^{\circ}$ 55871 de 26 de março de 1965 http://legis.senado.gov.br/legis lacao/DetalhaSigen.action?id=478463. Accessed 19 December 2017

ANVISA (Brazillian Health Regulatory Agency) (1998) Ordinance $n^{\circ}$ 685 of August 27, $1998 \mathrm{http} / / / \mathrm{bvsms}$.saude.gov.br/bvs/saudelegis /anvisa/1998/anexo/anexo_prt0685_27_08_1998.pdf/ Accessed 19 December 2017

Brazil (2013) Law n ${ }^{\circ} 12.890$ of December 10, 2013. Changes to Law $\mathrm{n}^{\circ} 6.894$ of December 16, 1980, to include remineralizers as an input category for agriculture, and other activities. http://www. planalto.gov.br/ccivil_03/_Ato2011-2014/2013/Lei/L12890.htm Accessed November 24, 2017

Chiodi Filho C (2014) Síntese das exportações brasileiras de rochas ornamentais em 2013. Abirochas, São Paulo

COPAM (Conselho Estadual de Política Ambiental) (2011) Resolução $\mathrm{n}^{\circ} 166$, de 29 de junho de 2011 http://www.siam.mg.gov.br/sla/ download.pdf?idNorma=18414. Accessed 05 January 2018

Cupertino MC, Souza MEP, Franco EH, Carvalho AMX, Cardoso IM (2015) Systematizing of experiences with rock powder in Minas Forest Zone. Cadernos de Agroecologia 10:1-5

Dumat C, Quenea K, Bermond A, Toinen S, Benedetti MF (2006) Study of the trace metal ion influence on the turnover of soil organic matter in cultivated contaminated soils. Environ Pollut. https://doi.org/10.1016/j.envpol.2005.10.027

European Commission. (2006) Commission Regulation (EU) $\mathrm{N}^{\circ}$ 1881/2006 of 19 December 2006 setting maximum levels for certain contaminants in foodstuffs. http://eur-lex.europa.eu/legal -content/EN/ALL/?uri=CELEX\%3A32006R1881. Accessed 12 December 2017

Ferreira ACB, Araújo GAA, Pereira PRG, Cardoso AA (2001) Características agronômicas e nutricionais do milho adubado com nitrogênio, molibdênio e zinco. Agric, Sci. https://doi. org/10.1590/S0103-90162001000100020

Gupta VK, Saleh TA (2013) Sorption of pollutants by porous carbon, carbon nanotubes and fullerene-an overview. Environ Sci Pollut Res. https://doi.org/10.1007/s11356-013-1524-1

Gupta VK, Nayak A, Agarwal S (2015) Bioadsorbents for remediation of heavy metals: current status and their future prospcets. Eng Res, Environ. https://doi.org/10.4491/eer.2015.018

IBRAM (Instituto Brasileiro de Mineração) (2012) Informações e análises da economia mineral Brasileira. Instituto Brasileiro de Mineração. $7^{\mathrm{a}}$ edição. http://www.ibram.org.br/sites /1300/1382/00002806.pdf Accessed 05 January 2018

Jeong CY, Young SD, Marshall SJ (2007) Competitive adsorption of heavy metals in humic substances by a simple ligand model. Soil Sci Soc Am J. https://doi.org/10.2136/sssaj2005.0281

Kabata-Pendias A (2010) Trace elements in soils and plants. CRC Press, Boca Raton

Kabata-Pendias A, Mukherjee AB (2007) Trace elements from soil to humans. Springer, Berlin. https://doi.org/10.1007/978-3-54032714-1

Liu D, Lian B, Wang B, Jiang G (2011) Degradation of potassium rock by earthworms and responses of bacterial communities in its gut and surrounding substrates after being fed with minerals. PLoS ONE. https://doi.org/10.1371/journal.pone.0028803

Losi ME, Amrhein C, Frankenberger WT (1994) Environmental biochemistry of chromium. In: Ware GW. (eds) Reviews of environmetal contamination and toxicology (Continuation 
of Residue Reviews). Springer, New York doi:https://doi. org/10.1007/978-1-4612-2656-7_3

Malavolta E (2006) Manual de nutrição mineral de plantas. Agronômica Ceres, São Paulo

MAPA (Ministry of Agriculture, Livestock, and Food Supply) (2006) Instrução Normativa ${ }^{\circ} 27$, de 5 jun. 2006. http://www.agricultur a.gov.br/assuntos/insumos-agropecuarios/insumos-agricolas/ fertilizantes/legislacao/in-sda-27-de-05-06-2006-alterada-pelain-sda-07-de-12-4-16-republicada-em-2-5-16.pdf. Accessed 24 November 2017

Marçal WS, Pardo PE, Nascimento MRL, Fortes MS (2005) Inorganic lead concentration in mineral salt commercial mixtures for beef cattle in São Paulo state, Brazil. Arq Inst Biol 73:339-341

Melamed R, Gaspar JC, Miekeley N (2008) Pó-de-rocha como fertilizante alternativo para sistemas de produção sustentáveis em solos tropicais. In: Lapido-Loureio FE, Melamed R, Neto JF (eds) Fertilizantes: agroindústria e sustentabilidade. The Mineral Technology Center - CETEM/MCT, Rio de Janeiro

Mengel K, Kirkby, EA (2001) Principles of plant nutrition. Kluwer Academic Publishers, Dordrecht, NL https://doi. org/10.1007/978-94-010-1009-2

Ramos CG, Querol X, Dalmora AC, Pires KCJ, Schneider IAH, Oliveira LFS, Kautzmann RM (2017) Evaluation of the potential of volcanic rock waste from southern Brazil as a natural soil fertilizer. J Clean Prod. https://doi.org/10.1016/j.jclepro.2016.11.006

Shtangeeva I, Steinnes E, Lierhagen S (2011) Macronutrients and trace elements in rye and wheat: similarities and differences in uptake and relationships between elements. Environ Exp Bot. https://doi. org/10.1016/j.envexpbot.2010.09.013

Silva FC (2009) Manual de análises químicas de solos plantas e fertilizantes. Embrapa Technological Information, Brasília

Souza MEP, Cardoso IM, Carvalho AMX, Lopes AP, Jucksch I, Janssen A (2018) Rock powder can improve vermicompost chemical properties and plant nutrition: an on-farm experiment. Commun Soil Sci Plant Anal https://doi.org/10.1080/00103624.2017.14183 72

Souza MEP, Carvalho AMX, Deliberali DC, Jucksch I, Brown GG, Mendonça ES, Cardoso IM (2013) Vermicomposting with rock powder increases plant growth. Appl Soil Ecol. https://doi. org/10.1016/j.apsoil.2013.01.016

Theodoro SH, Leonardos OH (2006) Sustainable farming with native rocks: the transition without revolution. An Acad Bras Ciênc http://dx.doi.org/10.1590/S0001-37652006000400007

Wei YY, Aziz NAA, Shamsuddin ZH, Mustafa M, Aziz SA, Kuan TS (2012) Enhancement of plant nutrient contents in rice straw vermicompost through the addition of rock phosphate. Malays, Acta Biol. https://doi.org/10.7593/abm/1.1.41

Publisher's Note Springer Nature remains neutral with regard to jurisdictional claims in published maps and institutional affiliations. 